\title{
Egg shell as a filler in composite materials - a review
}

Sakshi Shantharam KAMATH, Ravi Kumar CHANDRAPPA

DOI: 10.30464/jmee.2020.4.4.335

Cite this article as:

Kamath S. S., Chandrappa R. K. Egg shell as a filler in composite materials - a review. Journal of Mechanical and Energy Engineering, Vol. 4(44), No. 4, 2020, pp. 335-340

\section{VOLUME 4(44) | No. 4 | DECEMBER 2020}



Editor-in-Chief

Waldemar Kuczyński

Editor

Krzysztof Nadolny
Journal of Mechanical and Energy

Engineering

Website: jmee.tu.koszalin.pl

ISSN (Print): 2544-0780

ISSN (Online): 2544-1671

Volume: $4(44)$

Number: 4

Year: 2020

Pages: $335-340$

Article Info:

Received 19 November 2020

Accepted 11 December 2020

\section{Open Access}

This article is distributed under the terms of the Creative Commons Attribution 4.0 (CC BY 4.0) International License (http://creativecommons.org/licenses/by/4.0/), which permits unrestricted use, distribution, and reproduction in any medium, provided you give appropriate credit to the original author(s) and the source, provide a link to the Creative Commons license, and indicate if changes were made. 


\title{
EGG SHELL AS A FILLER IN COMPOSITE MATERIALS - A REVIEW
}

\author{
Sakshi Shantharam KAMATH ${ }^{1}$, Ravi Kumar CHANDRAPPA ${ }^{1 *}$ \\ ${ }^{1}$ Department of Chemistry, Alva's Institute of Engineering \& Technology, MIJAR-574225, Visvesvaraya \\ Technological University, Karnataka, India. \\ ${ }^{1 *}$ Department of Chemistry, Alva's Institute of Engineering \& Technology, MIJAR-574225, Visvesvaraya \\ Technological University, Karnataka, India. \\ Tel.: +918892540530. E-mail address: dr.ravikumarc@ aiet.org.in
}

(Received 19 November 2020, Accepted 11 December 2020)

\begin{abstract}
Current focus is on polymer and metal matrix composites for their increased mechanical properties. The strength of the composites is further enhanced by incorporating different types of additives which includes fillers, flame retardants, silanes, coupling agents and so on. One such additives is egg shell powder which influences the strength of composites and thus, gains the attention of researchers for its incorporation in composite fabrication. The work is in progress with respect to utilizing waste egg shell in composite fabrication, which not only finds solution for the waste disposal, but also enhances the strength of composites manufactured. This work is the compilation of work done by different researchers with egg shell in composites, so that the need of its utilization in the manufacture of composites will be stronger.
\end{abstract}

Keywords: natural fibre composites, chicken egg shell powder, mechanical property, water absorption property

\section{INTRODUCTION}

Composite materials are made up of one or more reinforcements (discontinuous phase) like fibres embedded in a matrix (continuous phase), resin. The composites are of three types which include metal matrix, ceramic matrix and polymer matrix composite. Polymer composites can be achieved with a wide variety of fibre reinforcements either synthetic in origin e.g. carbon fibre, glass fibres, aramid or natural fibres like flax, hemp, coir, abaca and sometimes hybrids too wherein both synthetic and natural fibres are used together [1]. Synthetic fibres to their credit have, good elasticity can handle heavy loads and are long lasting and are readily available than their natural counterparts. Though synthetic fibres are easy to produce and are available in plenty but come with a disadvantage that they are non-biodegradable and hence are not eco-friendly and leave a trail of carbon footprint right from their production and until disposal [2]. On the contrary, natural fibres are available in plenty either cultivated for the same or available as by-products of agricultural industry and their properties are comparable to synthetic fibres. Thus, natural fibre polymer composites (NFPC) are possible alternatives to the synthetic fibre composites and are fast replacing synthetic fibres in composite materials [3]. To any type of composites, additives are added, so as to bring about certain positive changes. Among many additives, fillers are the class of additives which when added fill the voids in the composites and because of this makes the end product much stronger. Red mud powder [4], coconut shell powder [5], tamarind extract powders [6] and egg shell powders are the popular natural fillers added.

The most commonly used inorganic filler nowadays in composite fabrication is calcium carbonate being water repellent. The easiest source available for $\mathrm{CaCO}_{3}$ is chicken egg shell which is produced in plenty every year as a waste material. In US, Environmental Protection Agency (EPA) has placed eggshell waste at $15^{\text {th }}$ place as a waste produced every year and the European Commission regulations treats egg shell as the most hazardous waste [7]. The major source of egg shell waste is poultries, food manufacturing industries, homes, 
bakeries and restaurants [8]. The waste management has become a challenging problem as a result of which scientists are giving prime importance for this waste disposal. Egg shells being inexpensive and light weight, finds its application in load bearing materials like automotive industry and other structural applications [9]. Hence, various researchers explored the utilization of this waste chicken egg shell as a reinforcement in variety of composites so that the strength of the composites is improved and also it thus, finds the way for its disposal [10].

\section{CHICKEN EGG SHELL AS A FILLER IN COMPOSITE FABRICATION}

Chicken egg consists of $60 \%$ of white coloured material which is called as albumin, $30 \%$ of yellow coloured material which is called as yolk and remaining $10 \%$ of the shell which gains the interest of research to be utilized as a filler in any kind of composite material [11]. The structure of an egg shell is shown in Fig. 1 [7]. The weight of the egg ranges form $60-60.2 \mathrm{~g}$ whereas the weight of the shell will be $6.6-7.3 \mathrm{~g}$ as discussed in literature [12]. This egg shell constitutes of $95 \%$ of calcium carbonate which is the strength giving material, with some number of organic proteins and moisture content. The other elements present in the egg shell are $\mathrm{MgO}(0.83 \%)$, $\mathrm{SO}_{3}(0.66 \%), \mathrm{P}_{2} \mathrm{O}_{5}(0.43 \%), \mathrm{Al}_{2} \mathrm{O}_{3}(0.15 \%), \mathrm{K}_{2} \mathrm{O}$ $(0.08 \%), \quad \mathrm{SiO}_{2}(0.07 \%), \mathrm{Cl}_{2} \mathrm{O}_{3} \quad(0.06 \%)$ and $\mathrm{SrO}$ $(0.04 \%)$ [13]. The density of the egg shell ranges from 2.50 to $2.65 \mathrm{~g} / \mathrm{cm}^{3}$ as reported in the literature [14-16]. Research is carried out by various scientists incorporating egg shell in different types of composite fabrication like metal matrix and polymer matrix composite. The mechanical property of the composites drastically increased with addition of egg shell particles. The major constituent of egg shell being $\mathrm{CaCO}_{3}$, the water-resistant property of the composites is increased. The investigations until the date, with respect to egg shell and the composites are reflected as follows.

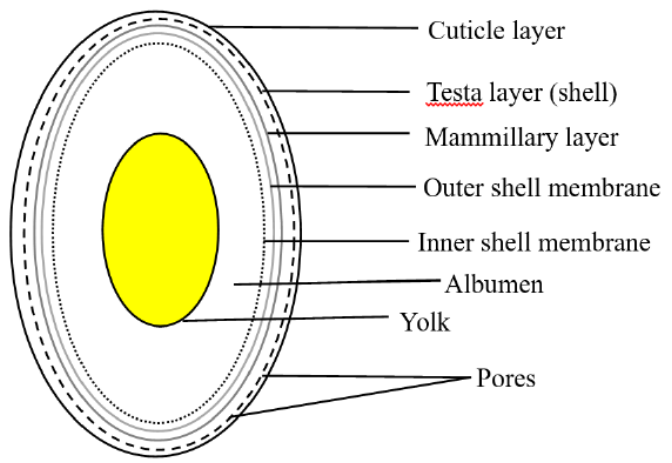

\section{MECHANICAL PROPERTIES OF THE COMPOSITES WITH EGG SHELL PARTICLES}

Egg shells are used as a reinforcement in the composites which has showed improvement in the strength of the composites. It is used as a filler in natural fibre composites, synthetic fibre composites, particulate, laminate and metal matrix composites. Few works have been carried out in this field where different combination of materials were considered to analyse the property of the composites fabricated. Results of the reported work are presented as Table 1. The incorporation of egg shell particles show better interaction with the resin thereby resulting in improved tensile, flexural, hardness, impact, shear strength of the composite materials.

\section{WATER ABSORPTION BEHAVIOUR OF EGG SHELL REINFORCED COMPOSITES}

Siti S. et al in the year 2009 studied the effect of egg shell particle on LDPE composites. Composites were manufactured by isophthalic acid modified and unmodified egg shell powder composites with different concentration of egg shell powder varying from $5-25 \%$. Water absorption studies was done with respect to ASTM D750-95. It was observed that LDPE showed minimum water absorption, whereas with increasing percentage of egg shell powder, the water absorption rate of the composites increased. This is because of the fact that with increasing percenatge of egg shell powder from $5 \%$ to $25 \%$, the filler agglomeration is observed which prevents the even distribution of filler and polymer matrix which thus increases teh water absorption of the composites [28]. Similar results were obtained by Ali et al in year 2020, who investigated how egg shell brings out the changes with water absorption with respect to egg shell-epoxy particulate composite [19]. ASTM D2842-12 was considered for the analysis. It was observed that with increase in the number of days; the composite exposed to water, the water absorption has increased. The rate of absorption is higher for initial 3-6 days whereas when exposed to 12-18 days, the rate of water absorption is comparatively lesser. After certain duration of time, the optimization is reached which further causes no change or very less change in the water absorption behaviour of the composite. The water absorption also increased with increasing egg shell concentration. The higher percentage of egg shell results in agglomeration resulting failure of the composites.

Fig. 1. Structure of an egg shell [7] 
Tab. 1. Mechanical property of the composites with egg shell powder

\begin{tabular}{|c|c|c|c|c|c|}
\hline Reinforcement & Resin/Composite & $\begin{array}{c}\text { Egg shell (ES) } \\
(\%)\end{array}$ & $\begin{array}{l}\text { Mechanical } \\
\text { properties }\end{array}$ & $\begin{array}{l}\text { Results obtained with } \\
\text { respect to egg shell } \\
\text { concentration }\end{array}$ & References \\
\hline Hemp fibre & Epoxy & $\begin{array}{c}7,14 \text { and } 21 \\
\text { (Nano particle) }\end{array}$ & $\begin{array}{c}\text { Tensile test (ASTM } \\
\text { D3039) } \\
\text { Shear test (ASTM } \\
\text { D2344) } \\
\text { Flexural test } \\
\text { (ASTM D790) } \\
\text { Impact test (ASTM } \\
\text { D 256) }\end{array}$ & $\begin{array}{l}\text { Tensile strength and shear } \\
\text { strength decreased with } \\
\text { increasing ES\% whereas } \\
\text { flexural strength and } \\
\text { impact strength increased } \\
\text { with increasing ES\% }\end{array}$ & $\begin{array}{l}\text { Bhoopathi et al } \\
\text { (2020) [17] }\end{array}$ \\
\hline Sisal fibre & Epoxy & $\begin{array}{c}\text { Calcined and } \\
\text { uncalcined }(3,6 \text {, } \\
9,12 \text { and } 15)\end{array}$ & $\begin{array}{c}\text { Flexural test } \\
\text { (ASTM D790) } \\
\text { Tensile test } \\
\text { (ASTMC1557) } \\
\text { Impact test } \\
\text { Hardness test }\end{array}$ & $\begin{array}{l}\text { Uncalcined ESP } \\
\text { composites with } 15 \% \text { ES } \\
\text { proportion gave good } \\
\text { mechanical properties to } \\
\text { the composite }\end{array}$ & $\begin{array}{c}\text { Oladele et al (2020) } \\
{[18]}\end{array}$ \\
\hline- & Epoxy & 10,20 and $30 \%$ & $\begin{array}{c}\text { Tensile test } \\
\text { Flexural test } \\
\text { Impact test (ASTM } \\
\text { 6957) } \\
\text { Hardness test } \\
\text { (ASTM 5091) }\end{array}$ & $\begin{array}{l}\text { Maximum hardness and } \\
\text { tensile strength were } \\
\text { observed for } 20 \% \text { egg } \\
\text { shell reinforced } \\
\text { composite, Maximum } \\
\text { flexural strength and } \\
\text { impact strength }-30 \% \\
\text { ESP }\end{array}$ & Ali et al (2020) [19] \\
\hline- & Epoxy & $4,8,12$ and 16 & $\begin{array}{c}\text { Hardness test } \\
\text { (ASTM D-2240) } \\
\text { Tensile test } \\
\text { (ASTM D 638) } \\
\text { Flexural test } \\
\text { (ASTM D790) } \\
\text { Impact test }\end{array}$ & $\begin{array}{c}\text { Strength of the } \\
\text { composites increased } \\
\text { with increasing ES \%. } \\
\text { Maximum result was } \\
\text { obtained for composites } \\
\text { with } 16 \% \text { ES. }\end{array}$ & $\begin{array}{c}\text { Ruaa et al (2019) } \\
{[20]}\end{array}$ \\
\hline- & Epoxy & 10,20 & $\begin{array}{c}\text { Flexural test } \\
\text { (ASTM D2344-84) } \\
\text { Vickers hardness } \\
\text { test }\end{array}$ & $\begin{array}{l}\text { Composites with } 20 \% \\
\text { ESP exhibited maximum } \\
\text { hardness and flexural } \\
\text { strength }\end{array}$ & $\begin{array}{c}\text { Shashir et al (2017) } \\
{[21]}\end{array}$ \\
\hline Glass fibre & Polyester & 5,10 & $\begin{array}{c}\text { Flexural test } \\
\text { (ASTM D7264) } \\
\text { Vickers hardness } \\
\text { test (ASTM E384) }\end{array}$ & $\begin{array}{l}5 \% \text { - greater flexural } \\
\text { strength } \\
\text { Same hardness for both } \\
5 \% \text { and } 10 \% \text { egg shell } \\
\text { composites }\end{array}$ & Pavan H (2016) [22] \\
\hline- & $\begin{array}{c}\text { Sugar sap } \\
100 / 1000 \text { epoxy }\end{array}$ & $\begin{array}{c}\text { Egg shell nano } \\
\text { powder (1-10 wt } \\
\%)\end{array}$ & $\begin{array}{l}\text { Flexural test } \\
\text { Modulus } \\
\text { Toughness }\end{array}$ & $\begin{array}{c}\text { Maximum for composite } \\
\text { with } 4 \text { wt } \% \text { of ES nano } \\
\text { powder }\end{array}$ & $\begin{array}{c}\text { Tiimob et al (2015) } \\
{[23]}\end{array}$ \\
\hline $\mathrm{Al}-\mathrm{Cu}-\mathrm{Mg}$ & $\begin{array}{l}\text { Particulate } \\
\text { composite }\end{array}$ & $\begin{array}{c}\text { Carbonized and } \\
\text { uncarbonized } \\
2-12 \\
\end{array}$ & $\begin{array}{c}\text { Tensile test } \\
\text { Flexural test } \\
\text { Impact test }\end{array}$ & $\begin{array}{c}\text { Carbonized } 12 \% \text { ES } \\
\text { gives better mechanical } \\
\text { property }\end{array}$ & $\begin{array}{c}\text { Hassan et al (2015) } \\
{[24]}\end{array}$ \\
\hline Calcium carbonate & Polyester & 15,20 & $\begin{array}{c}\text { Tensile test } \\
\text { (ASTM D 638) } \\
\text { Flexural test } \\
\text { (ASTM D 790) } \\
\text { Water absorption } \\
\end{array}$ & $\begin{array}{l}\text { 20\%-high tensile strength } \\
\text { 15\%-high flexural } \\
\text { strength } \\
\text { 20\%- greater water } \\
\text { absorption }\end{array}$ & Senthil J (2015) [25] \\
\hline $\mathrm{Al}$ & $\begin{array}{l}\text { Metal matrix } \\
\text { composite }\end{array}$ & $\begin{array}{l}2-12 \% \text { Egg shell } \\
\text { powder }\end{array}$ & $\begin{array}{l}\text { Tensile test } \\
\text { Hardness test }\end{array}$ & $\begin{array}{l}\text { Properties increased with } \\
\text { increasing ESP \% }\end{array}$ & $\begin{array}{l}\text { Agunsoye et al } \\
\text { (2015) [26] }\end{array}$ \\
\hline Calcium carbonate & $\begin{array}{l}\text { Polyethylene } \\
\text { from sugarcane }\end{array}$ & $\begin{array}{c}5,10,20,30 \text { and } \\
40\end{array}$ & $\begin{array}{c}\text { Tensile test } \\
\text { Flexural test } \\
\text { Impact test }\end{array}$ & $\begin{array}{l}\text { The strength of the } \\
\text { composite, decreased } \\
\text { with increasing ES \% }\end{array}$ & $\begin{array}{c}\text { Boronat et al (2014) } \\
\text { [13] }\end{array}$ \\
\hline Soy-protein isolate & - & $\begin{array}{c}\text { Egg shell nano } \\
\text { powder }(3,5 \text { and } \\
10 \mathrm{wt} \%)\end{array}$ & $\begin{array}{c}\text { Tensile test } \\
\text { Young's modulus }\end{array}$ & $\begin{array}{l}\text { Increased up to } 15 \% \text { after } \\
\text { which the strength } \\
\text { reduced }\end{array}$ & $\begin{array}{c}\text { Rahman et al (2014) } \\
\text { [27] }\end{array}$ \\
\hline
\end{tabular}


Bhoopathi et al in year 2020 studied the effect of variation of egg shell powder in the untreated and alkali treated hemp fibre reinforced epoxy composites [17]. With increasing egg shell powder concentration, the water absorption of the composites reduced which proves that egg shell can be used as a filler in composite fabrication. Rahim et al in year 2019, studied the effect of egg shell in epoxy composite according to ASTM D-570. It was observed that egg shell powder was used in increasing concentration of 4, 8, 12 and $16 \%$. With increasing concentration of egg shell powder, the water resistant property of the composites increased [20]. Similar results were shown by Shashir et al in year 2017, where the greater percentage of egg shell powder in epoxy composite decreased the water absorption behaviour of the composites [21].

\section{CONCLUSION}

Composites are the materials which gives superior property because of the combination of two different materials. In the field of composites, egg shell particles are of prime importance, because it increases mechanical strength of the composites manufactured and also gives the way for waste management. Through the literature, it is quite evident that the egg shell particles incorporated in any composites like metal matrix or polymer matrix; enhances the tensile strength, flexural strength, shear strength, impact strength and hardness at different concentrations of egg shell in combination of metal/fibres/resin at different fractions. The water absorption behaviour of the composites decreased drastically in case of natural fibre reinforced polymer composites after incorporation of egg shell particles. The work done in literature with respect to egg shell as a filler in natural fibre reinforced polymer composite is less. The tribological studies with respect to egg shell as fillers is still to be explored. Hence, after this review study, it is evident that; there is scope for utilization of egg shell particle as a filler in composites and to study their wear behaviour so that it can be used for any structural applications, automobile and marine applications in future.

\section{Acknowledgement}

Authors would like to thank Principal of Alva's Institute of Engineering and Technology, Moodbidri for his encouragement.

\section{Conflict of interest}

Authors declare there is no conflict of interest.

\section{References}

1. Azwa, Z. N. et al. (2013) 'A review on the degradability of polymeric composites based on natural fibres', Materials and Design, 47, pp. 424-442. DOI: 10.1016/j.matdes.2012.11.025

2. Thyavihalli Girijappa, Y. G. et al. (2019) 'Natural Fibers as Sustainable and Renewable Resource for Development of Eco-Friendly Composites: A Comprehensive Review', Frontiers in Materials, 6(September), pp. 1-14. DOI: 10.3389/fmats.2019.00226.

3. Kamath, S. S., Sampathkumar, D. and Bennehalli, B. (2017) 'A review on natural areca fibre reinforced polymer composite materials', Ciência \& Tecnologia dos Materiais, 29(3), pp. 106-128. DOI: 10.1016/ j.ctmat.2017.10.001.

4. Zhang, Y. et al. (2011) 'Red mud/polypropylene composite with mechanical and thermal properties', Journal of Composite Materials, 45(26), pp. 2811-2816. DOI: 10.1177/0021998311401937

5. Gopal, P. et al. (2017) 'Wear study on hybrid natural fiber epoxy composite materials used as automotive body shell', ARPN Journal of Engineering and Applied Sciences, 12(8), pp. 2485-2490.

6. Selvaraj, D. K. et al. (2019) 'Influence of the natural additive on natural fiber reinforced thermoplastic composite', in Procedia Manufacturing. Elsevier B.V., pp. 1121-1129. DOI: 10.1016/j.promfg.2020.01.200

7. Owuamanam, S. and Cree, D. (2020) 'Progress of BioCalcium Carbonate Waste Eggshell and Seashell Fillers in Polymer Composites: A Review', Journal of Composites Science, 4(2), p. 70. DOI: 10.3390/jcs4020070.

8. Mittal, A. et al. (2016) 'Applications of egg shell and egg shell membrane as adsorbents: A review', Journal of Molecular Liquids, 223, pp. 376-387. DOI: 10.1016/j.molliq.2016.08.065

9. Chaithanyasai, A., Vakchore, P. R. and Umasankar, V. (2014) 'The micro structural and mechanical property study of effects of EGG SHELL particles on the Aluminum 6061', Procedia Engineering, 97, pp. 961-967. DOI: 10.1016/j.proeng.2014.12.372

10. Ummartyotin, S., Pisitsak, P. and Pechyen, C. (2016) 'Eggshell and bacterial cellulose composite membrane as absorbent material in active packaging', International Journal of Polymer Science, 2016. DOI: 10.1155/2016/ 1047606

11. DSM egg quality manual.

12. John-Jaja, S. A., Udoh, U. H. and Nwokolo, S. C. (2016) 'Repeatability estimates of egg weight and egg-shell weight under various production periods for Bovan Nera Black laying chicken', Beni-Suef University Journal of Basic and Applied Sciences, 5(4), pp. 389-394. DOI: 10.1016/j.bjbas.2016.11.001

13. Boronat, T. et al. (2015) 'Development of a biocomposite based on green polyethylene biopolymer and eggshell', Materials and Design, 68, pp. 177-185. DOI: 10.1016/j.matdes.2014.12.027

14. Intharapat, P., Kongnoo, A. and Kateungngan, K. (2013) 'The Potential of Chicken Eggshell Waste as a Bio-filler Filled Epoxidized Natural Rubber (ENR) Composite and its Properties', Journal of Polymers and the Environment, 21(1), pp. 245-258. DOI: 10.1007/s10924-012-0475-9

15. Mohan, T. P. and Kanny, K. (2018) 'Thermal, mechanical and physical properties of nanoegg shell particle-filled epoxy nanocomposites', Journal of Composite Materials, 52(29), pp. 3989-4000. DOI: $10.1177 / 0021998318773445$

16. Pliya, P. and Cree, D. (2015) 'Limestone derived eggshell powder as a replacement in Portland cement mortar', Construction and Building Materials, 95, pp. 1-9. DOI: 10.1016/j.conbuildmat.2015.07.103. 
17. Bhoopathi, R. and Ramesh, M. (2020) 'Influence of Eggshell Nanoparticles and Effect of Alkalization on Characterization of Industrial Hemp Fibre Reinforced Epoxy Composites', Journal of Polymers and the Environment, 28(8), pp. 2178-2190. DOI: $10.1007 / \mathrm{s} 10924-020-01756-1$

18. Oladele, I. O. et al. (2020) 'Mechanical and wear behaviour of pulverised poultry eggshell/sisal fiber hybrid reinforced epoxy composites', Materials Research Express, 7(4). DOI: 10.1088/2053-1591/ab8585

19. Ali, J. B., O, Z. A. and Danladi, A. (2020) 'Preparation and Characterization of Epoxy Resin Reinforced Chicken Eggshell Particulate Composites', 1(1), pp. 131-138

20. Abdel-Rahim, R. H. and Mohammed, R. A. (2019) 'Experimental investigation of some properties of epoxy reinforced by egg shell particles', International Journal of Mechanical Engineering and Technology, 10(1), pp. $152-163$.

21. Máca, P., Sovják, R. and Vavřiník, T. (2013) 'Experimental investigation of mechanical properties of UHPFRC', Procedia Engineering, 65(07), pp. 14-19. DOI: 10.1016/j.proeng.2013.09.004

22. Hiremath, P. et al. (2018) 'Investigation on Effect of Egg Shell Powder on Mechanical Properties of GFRP Composites', Materials Today: Proceedings, 5(1), pp. 3014-3018. DOI: 10.1016/j.matpr.2018.01.101.

23. Tiimob, B. J., Jeelani, S. and Rangari, V. K. (2016) 'Eggshell reinforced biocomposite - An advanced "green" alternative structural material', Journal of Applied Polymer Science, 133(11), pp. 1-10. DOI: 10.1002/app.43124.

24. Hassan, S. B. and Aigbodion, V. S. (2015) 'Effects of eggshell on the microstructures and properties of $\mathrm{Al}-\mathrm{Cu}-$ $\mathrm{Mg}$ /eggshell particulate composites', Journal of King Saud University - Engineering Sciences, 27(1), pp. 4956. DOI: 10.1016/j.jksues.2013.03.001.

25. Senthil, J. and P, M. R. (2015) 'Preparation and Characterization of Reinforced Egg Shell Polymer Composites', International Journal on Mechanical Engineering and Robotics (IJMER), 3(3), pp. 7-17

26. Agunsoye, J. O. et al. (2015) 'Recycled aluminium cans/eggshell composites: Evaluation of mechanical and wear resistance properties', Tribology in Industry, 37(1), pp. 107-116.

27. Rahman, M. M. et al. (2014) 'Bioderived "green" composite from soy protein and eggshell nanopowder', ACS Sustainable Chemistry and Engineering, 2(10), pp. 2329-2337. DOI: 10.1021/sc5003193.

28. Shuhadah, S. and Supri, A. G. (2009) 'LDPE-Isophthalic Acid-Modified Egg Shell Powder Composites (LDPE/ESP I)', Journal of Physical Science, 20(1), pp. 87-98.

\section{Biographical notes}

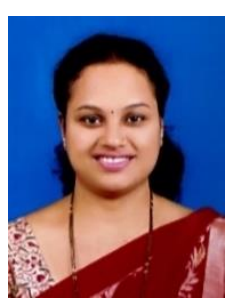

Mrs. Sakshi S Kamath pursued her Masters in Chemistry from NITK Surathkal in year 2012. She has 8 years of teaching experience and is currently pursuing her $\mathrm{PhD}$ in the field of Natrual fibre reinforced polymer composites under Visvesvaraya Technological University, Belagavi, Karnataka. She is currently working as an Assistant Professor in Department of Chemistry, Alva's Institute of Engineering and Technology, Moodbidri, Karnataka, India.

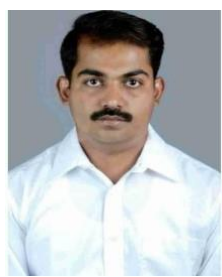

Dr. Ravi Kumar Chandrappa completed his $\mathrm{PhD}$ in Analytical Chemistry from University of Versailles St. Quentin, France in year 2011. He has an experience of more than 13 years in teaching and in Industry. His field of research is in Composite materials and Solid state NMR. He is currently working as Professor in Department of Chemistry, Alva's Institute of Engineering and Technology, Moodbidri, Karnataka, India. 
